\title{
PENGENDALIAN PENYAKIT BLAS (Pyricularia oryzae) PADA BEBERAPA VARIETAS PADI GOGO MENGGUNAKAN MIKORIZA INDIGENOUS DAN NON INDIGENOUS
}

\author{
Suriani $^{1}$, Fikrinda $^{2}$, dan Marlina ${ }^{* 1}$ \\ ${ }^{1}$ Jurusan Proteksi Tanaman, ${ }^{2}$ Jurusan Ilmu tanah \\ Fakultas Pertanian Universitas Syiah Kuala \\ Jl. Tgk. Hasan Krueng Kalee No.3 Kopelma Darussalam Banda Aceh \\ Email:marlina.fpunsyiah@gmail.com
}

\begin{abstract}
Abstrak
Suatu untuk pengendalian penyakit blas pada padi gog telah dilaksanakan di dalam Rumah Kasa Kebun Percobaan, Laboratorium Hama dan Penyakit Tanaman, dan Laboratorium Biologi Tanah Fakultas Pertanian Universitas Syiah Kuala, Band Aceh. Pelaksanaan penelitian dimulai pada bulan November 2017 sampai Februari 2018. Penelitian ini menggunakan Rancangan Acak Lengkap (RAL) pola faktorial yang terdiri atas 2 faktor dengan ulangan sebanyak 3 kali. Faktor pertama yaitu perlakuan mikoriza yang terdiri atas M1: Mikoriza Indigenous, M2: Mikoriza non Indigenous. Sedangkan faktor kedua yaitu varietas/padi gogo yang terdiri atas : varietas Situ Patenggang (V1), galur Unsyiah 01 Simeulu (V2), galur Unsyiah 05 Sibahak (V3), dan galur Unsyiah 07 Sibabus (V4).

Hasil penelitian menunjukkan bahwa mikoriza indigenous dan non indigenous tidak berpengaruh terhadap masa inkubasi dan persentase tanaman terserang penyakit blas pada varietas padi Situ Patenggang dan galur Unsyiah 01 Simeulu, Unsyiah 05 Sibahak, dan Unsyiah 07 Sibabus. 2). Mikoriza indigenous dapat menekan keparahan penyakit blas pada varietas Situ Patenggang dan galur Unsyiah 07 Sibabus. Sedang mikoriza non indigenous dapat menekan keparahan penyakit pada galur Unsyiah 01 Simeulu dan galur Unsyiah 05 Sibahak.
\end{abstract}

\section{PENDAHULUAN}

Penyakit blas merupakan salah satu penyakit penting pada tanaman padi gogo. Penyakit ini disebabkan oleh jamur Pyricularia oryzae (Wang et al., 2014) . Di Indonesia penyakit blas sudah menyebar hampir di semua sentera pertanaman padi seperti yang terjadi di Lampung dan Sumatera Selatan (Sudir et al., 2014., BBPTP, 2015). Sedangkan di Aceh penyakit ini banyak ditemukan pada padi masyarakat di Aceh Besar, Penyakit blas dapat menyebabkan tanaman padi gogo mati baik pada stadium vegetatif maupun generatif, sehingga dapat menyebabkan kegagalan panen hingga 100\% (Sobrizal et al., 2007).

*1. Co Author

Dosen Fakultas Pertanian Fakultas Universitas Syiah Kuala 
Upaya pengendaliannya adalah dengan menggunakan varietas tahan, tetapi $P$. oryzae mempunyai viabilitas yang cukup tinggi sehingga mudah terjadi perubahan status ketahanan. Selain itu, cendawan $P$. oryzae mempunyai banyak tanaman inang dan mampu bertahan hidup di tanah terutama pada tanah-tanah yang banyak mengandung bahan organik (Semangun 1993). Pengendalian penyakit blas juga dapat dilakukan dengan rotasi tanaman dan aplikasi fungisida. Penggunaan fungisida yang efektif dan terus-menerus menyebabkan terjadinya resistensi tanaman terhadap patogen tertentu, bahkan dapat menimbulkan strain baru, sehingga penggunaan mikroorganisme sebagai pengendali hayati mulai dilakukan (Semangun 2001).

Pengendalian secara hayati dimaksudkan untuk menghindari dampak negatif pengendalian secara kimiawi, yaitu terjadinya resistensi patogen dan pencemaran lingkungan. Simbiosis antara cendawan mikoriza arbuskular (CMA) dan tanaman dilaporkan dapat meningkatkan ketahanan dan telah banyak diuji, misalnya pada jeruk, kapas, kedelai, dan tomat (Cordier et al. 1998). Meningkatnya ketahanan tanaman terhadap penyakit karena adanya asosiasi antara tanaman dengan CMA, beberapa jenis cendawan mikoriza yang diuji terbukti mampu menurunkan tingkat kerusakan tanaman yang disebabkan oleh beberapa pathogen, terutama patogen tular tanah (Agrios 1997). Smith et al. (2003) mengemukakan bahwa kondisi optimum dan jenis CMA yang diintroduksi dapat meningkatkan keefektifan dan kemampuan bersaing dengan CMA alami. Penelitian ini bertujuan untuk mengetahui pengaruh mikoriza indigenous dan non indigenous terhadap penyakit blas pada padi gogo.

\section{BAHAN DAN METODE PENELITIAN}

\section{Tempat dan Waktu Penelitian}

Penelitian ini dilaksanakan di dalam Rumah Kasa Kebun Percobaan, Laboratorium Hama dan Penyakit Tanaman, dan Laboratorium Biologi Tanah Fakultas Pertanian Universitas Syiah Kuala, Band Aceh. Pelaksanaan penelitian dimulai pada bulan November 2017 sampai Februari 2018. Penelitian ini menggunakan Rancangan Acak Lengkap (RAL) pola faktorial yang terdiri atas 2 faktor dengan ulangan sebanyak 3 kali. Faktor pertama yaitu perlakuan mikoriza yang terdiri atas M1: Mikoriza Indigenous, M2: Mikoriza non Indigenous. Sedangkan faktor kedua yaitu beberapa varietas/galur padi gogo

*1. Co Author

Dosen Fakultas Pertanian Fakultas Universitas Syiah Kuala 
yang terdiri atas : varietas Situ Patenggang (V1), galur Unsiyah 01 Simeulu (V2), galur Unsiyah 05 Sibahak (V3), dan galur Unsiyah 07 Sibabus (V4).

\section{Alat yang digunakan}

Alat yang digunakan dalam penelitian ini adalah satu set saringan bertingkat ( 600 $\mu \mathrm{m}, 250 \mu \mathrm{m}, 53 \mu \mathrm{m}$, dan $38 \mu \mathrm{m}$ ), beaker glass, sentrifus, pinset spora, gunting, saringan teh, mikroskop, tabung reaksi, autoclave, lampu bunsen, petridish, timbangan analitik, laminator air flow, erlenmeyer, pinset, jarum ose, kuas steril, kain saring steril, meteran, penggaris, botol semprot, pot ukuran $10 \mathrm{~kg}$, pot aqua gelas, gembor, sprayer, wadah persemaian, kertas label, koran dan alat tulis.

\section{Bahan yang digunakan}

Bahan yang digunakan dalam penelitian ini adalah benih padi gogo varietas Situ Patenggang, Unsyiah 01 Simeulu, Unsyiah 05 Sibahak, dan Unsyiah 07 Sibabus. Pupuk kandang, pupuk Urea (0,75 g), KCL (0,25 g) dan SP-36 (0,38 g), tanah Inseptisol, aquades, air Reverse Osmosis (RO), Potato Dextrose Agar (PDA), alkohol 70\%, aluminium foil, kertas merang, inokulan mikoriza indigenous (Acaulospora sp) dari perakaran padi gogo yang diperoleh dari hasil perbanyakan koleksi Laboratorium Biologi Tanah Unsyiah, inokulan mikoriza non indigenous (Acaulospora sp, Glomus manihot, Gigaspora margarita) diperoleh dari Laboratorium Bioteknologi Hutan dan Lingkungan IPB Bogor, isolat Pyricularia oryzae diperoleh dari rizosfer padi gogo di kebun Pertanian Unsyiah.

\section{Pelaksanaan Penelitian}

Persiapan Media Tanam

Media tanam yang digunakan dalam penelitian ini adalah bahan tanah Inseptisol dan pupuk kandang dengan perbandingan 2:1. Media tersebut dimasukkan ke dalam setiap pot sebanyak $10 \mathrm{~kg}$ dan diberikan air sampai kapasitas lapang. selanjutnya diaduk sampai merata.

Aplikasi Mikoriza dan Penanaman

*1. Co Author

Dosen Fakultas Pertanian Fakultas Universitas Syiah Kuala 
Aplikasi mikoriza sesuai dengan perlakuan yaitu sebanyak $10 \mathrm{~g}$ di tempatkan dalam lubang tanam pada kedalaman $5 \mathrm{~cm}$, dan ditanami bibit yang telah berumur 7 HST sebanyak satu bibit per pot, kemudian lubang tanah ditutup dengan tanah.

Inokulasi Isolat Pyricularia oryzae

Inokulasi isolat $P$. oryzae dilakukan ke bagian daun padi pada umur 30 hari setelah tanam, yaitu dengan menyemprotkan suspensi spora dengan kerapatan $10^{5}$ konidia $/ \mathrm{ml}$ larutan yang telah disiapkan ke tanaman padi gogo. Tanaman yang telah diinokulasi ditempatkan dalam ruang lembab sampai timbul gejala penyakit blas pada tanaman padi gogo. Ruang lembab tersebut dibuat dengan sungkup plastik di dalam rumah kasa. Pada ruang lembab tersebut dilakukan penyemprotan air dengan menggunakan sprayer agar untuk kelembaban dan pengembunan. Setelah gejala $P$. oryzae muncul pada tanaman padi gogo yang diperlakukan sungkup plastik dibuka.

\section{Peubah yang Diamati}

\section{Masa Inkubasi}

Pengamatan masa inkubasi dilakukan setiap hari setelah inokulasi sampai tanaman memperlihatkan gejala pertama yang ditandai terjadinya bercak kecil pada permukaan daun dan batang padi gogo sebesar ujung jarum atau lebih dan berwarna coklat, daun yang menimbulkan bercak diukur menggunakan diagram area buku. Pengamatan dilakukan mulai satu hari setelah inokulasi (HSI).

\section{Persentase Daun Terserang}

Pengamatan persentase daun terserang dihitung pada saat tanaman mulai menimbulkan bercak pada daun padi yang terserang. Persentase daun terserang dihitung menggunakan rumus (Hakkar et al., 2014) sebagai berikut:

$$
\mathbf{P}=\frac{a}{b} \times 100 \%
$$

Keterangan :

*1. Co Author

Dosen Fakultas Pertanian Fakultas Universitas Syiah Kuala 
$\mathrm{P} \quad=$ Persentase daun terserang

a $\quad=$ Jumlah daun yang menunjukkan gejala serangan

$\mathrm{b} \quad=$ Jumlah daun yang diamati

\section{Keparahan Penyakit}

Keparahan penyakit dihitung berdasarkan skala kerusakan dengan rumus :

$K P=\frac{\sum(n x v)}{N x V} \times 100 \%$

Keterangan :

$\mathrm{KP}=$ Keparahan penyakit tanaman

$\mathrm{n} \quad=$ Jumlah sampel tanaman yang diamati pada setiap skala kerusakan

$\mathrm{v} \quad=$ Nilai skala kerusakan

$\mathrm{N} \quad=$ Total jumlah sampel tanaman yang diamati

$\mathrm{V} \quad=$ Nilai skala kerusakan tertinggi

\section{HASIL DAN PEMBAHASAN}

\section{Masa Inkubasi Penyakit Blas (hari)}

Hasil analisis ragam menunjukkan bahwa tidak ada pengaruh interaksi antara mikoriza dengan varietas padi gogo yang diuji terhadap masa inkubasi penyakit blas. Faktor tunggal mikoriza juga tidak menunjukkan bengaruh nyata terhadap masa inkubasi. Hanya faktor varietas yang menunjukkan pengaruh nyata terhadap masa inkubasi penyakit blas pada beberapa varietas padi gogo yang diuji. Rata-rata masa inkubasi penyakit blas akibat pemberian mikoriza indigenous dan non indigenous pada beberapa varietas padi gogo dapat dilihat pada Tabel 1.

Tabel 1. Rata-rata Masa Inkubasi Pyricularia oryzae Akibat Pengaruh Jenis Mikoriza pada beberapa Varietas Padi Gogo terhadap P. oryzae (HSI)

\begin{tabular}{lccccc}
\hline \multirow{2}{*}{ Jenis Mikoriza } & \multicolumn{4}{c}{ Varietas Padi Gogo } & \multirow{2}{*}{ Rata-rata } \\
\cline { 2 - 5 } & $\mathrm{V}_{1}$ & $\mathrm{~V}_{2}$ & $\mathrm{~V}_{3}$ & $\mathrm{~V}_{4}$ & \\
\hline Indigenous & 2,21 & 3,57 & 2,90 & 4,07 & 3,19
\end{tabular}

*1. Co Author

Dosen Fakultas Pertanian Fakultas Universitas Syiah Kuala 


\begin{tabular}{cccccc} 
Non Indigenous & 1,82 & 3,94 & 4,05 & 3,31 & 3,28 \\
\hline Rata-rata & $2,02 \mathrm{~A}$ & $3,75 \mathrm{~B}$ & $3,47 \mathrm{~B}$ & $3,69 \mathrm{~B}$ & \\
\hline
\end{tabular}

Keterangan : angka-angka yang diikuti oleh huruf yang sama tidak berbeda nyata berdasarkan Uji BNT pada taraf 0,05.

Masa inkubasi terlama ditemukan pada perlakuan mikoriza non indigenous yaitu 3,28 hari tetapi tidak berbeda nyata pada perlakuan mikoriza indigenous yaitu 3,19 hari. Meskipun demikian Hasil penelitian ini menunjukkan bahwa mikoriza non indigenous cenderung dapat memperpanjang masa inkubasi penyakit blas pada padi gogo. Menurut Saragih (2009) bahwa mikoriza indigenous dan non indigenous mempunyai peranan penting dalam meningkatkan kesehatan tanaman serta mengendalikan patogen pada tanaman atau menginduksi ketahanan sistemik tanaman.Tanaman bermikoriza akan lebih tahan terhadap serangan patogen akar. Tanaman yang bermikoriza juga dapat mendorong terciptanya lingkungan yang tidak cocok bagi pertumbuha patogen, karena mikoriza menyerap semua kelebihan karbohidrat dan eksudat akar ( Zak, 1967 dalam Imas, dkk,. 1989).

Ketahanan tanaman padi gogo terhadap penyakit blas berbeda-beda tergantung pada varietas. Hasil penelitian ini menunjukkah bahwa galur Unsyiah 01Simeulu (V2), Unsyiah 05 Sibahak (V3), dan Unsyiah 07 Sibabus (V4) lebih tahan terhadap gangguan penyakit blas dibandingkan dengan varietas Situ Patenggang (V1).

\section{Persentase Daun Terserang (\%)}

Hasil analisis ragam menunjukkan bahwa tidak ada pengaruh interaksi antara mikoriza dengan varietas padi gogo yang diuji terhadap persentase daun terserang penyakit blas. Persentase daun terserang akibat pemberian mikoriza indigenous dan non indigenous pada beberapa varietas padi gogo dapat dilihat pada Tabel 2.

Tabel 2. Rata-rata Persentase Daun Terserang Penyakit Blas Akibat Pemberian Mikoriza Indigenous dan non Indigenous pada Varietas dan galur Padi Gogo (30 HSI)

\begin{tabular}{lccccc}
\hline \multirow{2}{*}{ Jenis Mikoriza } & \multicolumn{4}{c}{ Varietas Padi Gogo } & \multirow{2}{*}{ Rata-rata } \\
\cline { 2 - 5 } & $\mathrm{V}_{1}$ & $\mathrm{~V}_{2}$ & $\mathrm{~V}_{3}$ & $\mathrm{~V}_{4}$ & \\
\hline Indigenous & 47,01 & 52,86 & 59,00 & 48,85 & $51,93 \mathrm{a}$ \\
Non Indigenous & 61,92 & 47,30 & 57,00 & 46,92 & $53,29 \mathrm{a}$ \\
\hline \multicolumn{1}{c}{ Rerata } & $54,46 \mathrm{~b}$ & $50,07 \mathrm{~b}$ & $58,00 \mathrm{~b}$ & $47,88 \mathrm{~b}$ & \\
\hline
\end{tabular}

*1. Co Author

Dosen Fakultas Pertanian Fakultas Universitas Syiah Kuala 
Keterangan : angka-angka yang diikuti oleh huruf yang sama tidak berbeda nyata berdasarkan Uji BNT pada taraf 0,05.

Tabel 2 menunjukkan bahwa aplikasi mikoriza indigenous dan non indigenous tidak mempengaruhi persentase daun terserang penyakit blas pada beberapa varietas dan galur padi gogo yang diuji. Perlakuan mikoriza indigenous menghasilkan persentase daun terserang penyakit blas sebesar 51,93\%. Demikian juga dengan perlakuan menggunakan mikoriza non indigenous menghasilkan persentase daun terserang relatif sama yaitu 53,29\%. Dari faktor varietas menunujukkan bahwa varietas Situ Patenggang (v1), galur Unsyiah 01 Simeulu (v2), dan Unsyiah 05 Sibahak (v3) menghasilkan persentase daun terserang lebih besar (> 50\%) yaitu berturut-turut 54,465\%, 50,079\%, dan 58,001\%. Sedangka persentase daun terserang pada padi galur Unsyiah 07 Sibabus (v4) lebih kecil (< $50 \%$ ) yaitu $47,884 \%$.

\section{Persentase Keparahan penyakit (\%)}

Hasil analisis ragam menunjukkan bahwa ada interaksi antara mikoriza dengan varietas/padi gogo yang diuji terhadap persentase keparahan penyakit. Persentase keparahan penyakit akibat pemberian mikoriza indigenous dan non indigenous pada beberapa varietas dan galur padi gogo dapat dilihat pada Tabel 3.

Tabel 3. Rata-rata Persentase Keparahan Penyakit Blas Akibat Pemberian Mikoriza Indigenous dan non Indigenous pada beberapa Varietas dan galur Padi Gogo (4 MSI)

\begin{tabular}{lcccc}
\hline Perlakuan & \multicolumn{4}{c}{ Varietas/galur Padi Gogo } \\
\cline { 2 - 5 } Mikoriza & $\mathrm{V} 1$ & $\mathrm{~V} 2$ & $\mathrm{~V} 3$ & $\mathrm{~V} 4$ \\
\hline Indigenous & $36,67 \mathrm{a}$ & $40,78 \mathrm{c}$ & $42,51 \mathrm{~b}$ & $35,06 \mathrm{~d}$ \\
Non Indigenous & $\mathrm{A}$ & $\mathrm{B}$ & $\mathrm{B}$ & $\mathrm{A}$ \\
& $43,08 \mathrm{~b}$ & $37,43 \mathrm{~d}$ & $39,42 \mathrm{a}$ & $36,46 \mathrm{~d}$ \\
& $\mathrm{~A}$ & $\mathrm{C}$ & $\mathrm{C}$ & $\mathrm{C}$ \\
\hline
\end{tabular}

Keterangan : Angka yang diikuti oleh huruf kecil yang sama arah kolom dan huruf kapital arah baris menunjukkan tidak berbeda nyata pada taraf Uji BNT $0,05 \%$.

Tabel 3 menunjukkan bahwa keparahan penyakit pada varietas Situ Patenggang (V1) dan galur Unsyiah 07 Sibabus (V4) nyata lebih rendah pada perlakuan mikoriza indigenous jika dibandingkan galur Unsyiah 01 Simeulu (V2) dan Unsyiah 05 Sibahak (V3). Tetapi dengan perlakuan mikoriza non indigenous keparahan penyakit pada varietas 
Situ Patenggang (V1) menunjukkan peningkatan dan menurun secara nyata pada galur Unsyiah 01 Simeulu (V2) dan unsyiah 05 Sibahak (V3).

Keparahan penyakit berkaitan dengan sifat ketahanan suatu tanaman terhadap suatu penyakit. Keparahan ini akan berdampak pada pertumbuhan dan produksi tanaman padi gogo. Pada tanaman yang bergejala relatif ringan kemungkinan masih dapat menghasilkan walaupun mengalami penurunan, sedangkan tanaman yang keparahannya tinggi dapat menyebabkan gagal panen (puso) (Rahmawaty et al., 2015).

\section{KESIMPULAN}

Berdasarkan hasil yang diperoleh dari penelitian ini maka dapat disimpulkan beberapa hal sebagai berikut: 1). Aplikasi mikoriza indigenous dan non indigenous tidak berpengaruh terhadap masa inkubasi dan persentase tanaman terserang penyakit blas pada varietas Situ Patenggang dan galur Unsyiah 01 Simeulu, Unsyiah 05 Sibahak, dan Unsyiah 07 Sibabus. 2). Mikoriza indigenous dapat menekan keparahan penyakit blas pada varietas Situ Patenggang dan galur Unsyiah 07 Sibabus. Sedang mikoriza non indigenous dapat menekan keparahan penyakit pada galur Unsyiah 01 Simeulu dan galur Unsyiah 05 Sibahak.

\section{DAFTAR PUSTAKA}

Agrios, G.N. 2004. Plant Pathology Fifth Edition. Elsevier Academic Press, New York.

BBPTP. 2015. Penyakit Blas Pada Tanaman Padi dan Cara Pengendaliannya. Website : bbpadi.litbang.pertanian.go.id. BB PADI. Jawa Barat.

Hakkar, A.A., R. Ade dan M.D. Rahim. 2014. Pengendalian Penyakit busuk buah kakao Phytophthora palmivora dengan cendawan endofit Trichoderma asperllum. Jurnal Pitopatologi Indonesia. 10: 139-144.

Nirmalasari. 2005. Keberadaan cendawan mikoriza arbuskula (CMA) pada tegakan durian (Durio ziberthinus Murr.). Skripsi. Fakultas Kehutanan UNTAN, Pontianak.

Rahmawaty, Y. S. Sulandari dan S. Hartono. 2015. Respons lima varietas padi terhadap infeksi virus penyebab penyakit kerdil rumput (Rice Grassy Stunt Virus). PROS SEMNAS MASY BIODIV INDON. 1(5): 1123-1126

*1. Co Author

Dosen Fakultas Pertanian Fakultas Universitas Syiah Kuala 
Saragih, F.J. 2009. Pengaruh Media Tanam dan Pemberian Mikoriza Vesikula Arbuskula (MVA) Terhadap Pertumbuhan Stump Mata Tidur Karet (Havea brasiliessis Muell.Arg.) [Skripsi]. Universitas Sumatra Utara, Medan.

Sobrizal, Santoso, Anggiani dan Suwarno. 2007. Rica blast disease in Indonesia. Dalam M. Casiana, V. Crus dan N. Kabyashi (Eds.). A Differential System for Blast Resistance for Stable Rice Production Environment. JIRCAS, Tsukuba dan IPGRI, Rome. Hal: 71-80.

Smith, S.E dan D.J. Read. 2008. Mycorrhizal Symbiosis. Third edition. Academic Press, New York, London, Burlington, San Diego.

Sudir, A. Nasution, Santoso dan B. Nuryanto. 2014. Penyakit blas Pyricularia grisea pada tanaman padi dan strategi pengendaliannya. Jurnal Iptek Tanaman Pangan. 9: 8596.

Wang, X., S. Lee, J. Wang, J.Ma, T. Bianco dan Y. Jia. 2014.Current advances on genetic resistance to rice blast disease. Dalam W. Yan dan J. Bao (Eds.). Rice-Germpam, Genetics and Improvement. JIRCAS, dan IPGRI, Rome. Hal: 234-347. 